\section{Diagnosis of personality disorders in learning}

\section{disability*}

REGI ALEXANDER and SHERVA COORAY
The diagnosis of personality disorders is fraught with methodological, clinical and ethical controversies (Tyrer et al, 1993). Although these difficulties are more evident in the context of learning disability, their diagnosis is still significant because it may affect the patient's acceptance into community placements (Reid \& Ballinger, 1987), predict subsequent psychiatric disorders (Goldberg et al, 1995), determine the rate of referrals to psychiatric services (Khan et al, 1997) and significantly influence the mode of management (Hurley \& Sovner, 1995; Mavromatis, 2000; Wilson, 2001). This selective review will examine published literature on the diagnosis of personality disorders in learning disability.

\section{METHOD}

Selective review with computerised (Medline, Embase and PsychInfo) and manual literature searches of the past 30 years.

\section{RESULTS}

\section{Problems in diagnosis}

The key themes are listed below.

(a) In those with average ability, lasting personality characteristics develop by adolescence. However, the developmental phase for personality characteristics among people with learning disability should be longer (Royal College of Psychiatrists, 2001).

(b) Communication problems, physical, sensory and behavioural disorders associated with learning disability affect the ability to diagnose a personality disorder (Khan et al, 1997). The diagnosis of personality disorders often requires subjective information about thoughts and emotions, difficult to elicit in those with severe degrees of learning disability. Consequently, a particular pattern of behaviour diagnosed as 'personality disorder' in those with mild or moderate learning disability may be perceived as 'behavioural disorder' in those with severe or profound disability.

(c) The criteria for several personality disorders assume a level of cognitive ability which may be absent in those with learning disability. Dissocial (Goldberg et al, 1995) and paranoid personality disorders are examples. Difficulties in establishing concepts such as 'preoccupation with unsubstantiated, conspiratorial explanations of events either immediate to the patient or in the world at large' in a group with significant cognitive limitations are self-evident.

(d) Further problems include the lack of valid, reliable instruments (Khan et al, 1997), differences between ICD-10 (World Health Organization, 1992) and DSM-IV (American Psychiatric Association, 1994), confusion of definition and different personality theories (Goldberg et al, 1995) and the difficulty in distinguishing personality disorders from late effects of childhood psychosis (Corbett, 1979).

(e) People with learning disability often display behaviours that overlap with features of some personality disorders.

\section{Schizoid/anancastic personality disorder}

Earlier studies (Craft, 1959) suggested that schizoid personalities were very common in people with learning disability. A significant proportion of these may actually have had autism (Deb \& Hunter, 1991). Autistic traits also overlap significantly with features of anancastic personality disorder.

\section{Emotionally unstable (borderline) personality disorder}

Features of borderline personality disorder, such as self-injurious behaviour, impulsivity and affective lability, occur commonly in learning disability (Mavromatis, 2000). Consequently, additional features should be sought before making this diagnosis (Wilson, 2001). Affective disorders commonly found in learning disability also mimic features of emotionally unstable personalities (Deb \& Hunter, 1991). 
Table I Studies on personality disorder in learning disability

\begin{tabular}{|c|c|c|c|c|}
\hline Study & Setting & Prevalence & $\begin{array}{l}\text { Range of learning } \\
\text { disability }\end{array}$ & Comments \\
\hline Corbett (1979) & Community & $25.4 \%$ & Full, Age 15 years+ & $\begin{array}{l}\text { - } \text { ICD-8 diagnosis } \\
\text { - No differentiation between behavioural and } \\
\text { personality disorders }\end{array}$ \\
\hline $\begin{array}{l}\text { Eaton \& Menolascino } \\
\qquad(1982)\end{array}$ & Community & $27.1 \%$ & $\begin{array}{l}\text { Full, } \\
\text { Age 6-76 years }\end{array}$ & - DSM-III diagnosis \\
\hline Day (1985) & Hospital & $\begin{array}{l}50.57 \% \\
\text { (long-stay patients) } \\
35.7 \% \\
\text { (new admissions) }\end{array}$ & Full & $\begin{array}{l}\text { - ICD-9 diagnosis } \\
\text { - No differentiation between behavioural and } \\
\text { personality disorders } \\
\text { - Personality disorder related to intellectual } \\
\text { level (explosive in severe and antisocial in mild) }\end{array}$ \\
\hline Gostasson (1987) & Population survey & $3 \%$ & & \\
\hline Ballinger \& Reid (1987) & Hospital & $\begin{array}{l}22 \% \text { (personality disorder), } \\
56 \% \text { (abnormal personality) }\end{array}$ & Mild to moderate & - ICD-9 diagnosis, based on SAP \\
\hline Jacobson (1990) & Community & $\begin{array}{l}5.06 \% \text { (aged below } 21) \\
3.99 \%(\text { aged } 22+)\end{array}$ & $\begin{array}{l}\text { Full, children and } \\
\text { adults }\end{array}$ & - DSM-II diagnosis \\
\hline Reiss (1990) & Community & $\begin{array}{l}25-45 \% \text { (personality disorder } \\
\text { symptoms) }\end{array}$ & Full, Age 12 yearst & $\begin{array}{l}\text { - Reiss screen and clinical assessment } \\
\text { - Categorical diagnosis not used }\end{array}$ \\
\hline Deb \& Hunter (199I) & $\begin{array}{l}\text { Hospital and } \\
\text { community }\end{array}$ & $\begin{array}{l}36 \% \text { (hospital), less than I\% } \\
\text { (community) }\end{array}$ & Mild to moderate & $\begin{array}{l}\text { - Comparison of those with and without } \\
\text { epilepsy } \\
\text { - Used SAP and T-LPBI } \\
\text { - No differences between the epileptic and } \\
\text { non-epileptic groups }\end{array}$ \\
\hline $\begin{array}{l}\text { Bouras \& Drummond } \\
\text { (1992) }\end{array}$ & Community & $6.9 \%$ & $\begin{array}{l}\text { Subjects with } \\
\text { expressive } \\
\text { language }\end{array}$ & - DSM-III-R diagnosis \\
\hline Goldberg et al (1995) & $\begin{array}{l}\text { Community and } \\
\text { hospital }\end{array}$ & $\begin{array}{l}\text { Abnormal personality - } \\
57 \% \text { in institutions and } \\
91 \% \text { in community }\end{array}$ & Full & $\begin{array}{l}\text { DSM-III-R diagnosis after Reiss screen and } \\
\text { PIMRA }\end{array}$ \\
\hline Khan et al (1997) & Community & $\begin{array}{c}50 \% \text { (personality abnormalities) } \\
31 \% \text { (personality disorder) }\end{array}$ & Full & - ICD-10 diagnosis based on SAP \\
\hline Naik et al (2002) & Community & $7 \%$ & Mild to moderate & - ICD-I0 diagnosis after clinical assessment \\
\hline Alexander et al (2002) & Hospital & $58 \%$ & Full range & $\begin{array}{l}\text { - Referrals to a medium secure service in } \\
\text { learning disability over a 40-month period } \\
\text { - ICD-I0 diagnosis }\end{array}$ \\
\hline Flynn et al (2002) & Hospital & $\begin{array}{l}\text { 39\% ('severe' personality } \\
\text { disorder), } 92 \% \\
\text { (personality disorder) }\end{array}$ & Mild to moderate & $\begin{array}{l}\text { - ICD-I0 diagnosis based on SAP } \\
\text { - Used criteria to define 'severe' personality } \\
\text { disorder }\end{array}$ \\
\hline
\end{tabular}

SAP, Structured Assessment of Personality; T-LPBI, Temporal-Lobe Personality Behaviour Inventory; PIMRA, Psychopathology Inventory for Mentally Retarded Adults.

Dependent and anxious/avoidant personality disorder

The presence of realistic dependency needs (Reid \& Ballinger, 1987) means that several criteria underpinning the diagnosis of dependent and anxious/avoidant personality disorders may be difficult to apply in learning disability.

The ability to diagnose personality disorders, inclusive of all sub-categories across the whole spectrum of learning disability, is hence debatable. Reviews of the published research literature fail to provide conclusive evidence.

\section{Assessment/research instruments used}

Instruments used in studies of personality disorders in learning disability are described below.
Structured Assessment of Personality (SAP)

The SAP (Mann et al, 1981) relies on an informant account to establish a diagnosis of personality disorder (Ballinger $\&$ Reid, 1987, 1988; Reid \& Ballinger, 1987). The presence of three or more durable criteria establishes a personality trait. If this causes significant personal distress, or occupational or social impairment, the diagnosis of personality disorder is made. 


\section{Reiss screen and PIMRA}

The Reiss screen is a screening tool for the detection of psychopathology in mental retardation (Reiss, 1988). For those scoring above a threshold, the Psychopathology Inventory for Mentally Retarded Adults (PIMRA; Matson, 1988) is administered (a checklist of psychopathological behaviour based on DSM-III).

\section{Temporal-Lobe Personality Behaviour Inventory}

This instrument is useful in identifying abnormal personalities specifically associated with epilepsy (Bear \& Fedio, 1977).

\section{'Clinical' diagnosis - ICD and DSM}

Most studies have used 'clinical' diagnoses based on either the ICD or DSM systems to identify personality disorders. The standard categories within these classificatory systems have sometimes been augmented with additional items, e.g. Immature and Impulsive (Corbett, 1979).

\section{Diagnostic Criteria in Learning Disability (DC-LD)}

Adopting a multi-axial, hierarchical approach to diagnosis, the DC-LD is a new system providing operationalised criteria for psychiatric disorders in adults with moderate to profound learning disabilities (Royal College of Psychiatrists, 2001). The key points regarding personality disorders are summarised below.

(a) The ICD-10 category of organic personality disorder should not be used purely on the grounds that a person has a learning disability, or a learning disabilities syndrome with an associated behavioural phenotype or epilepsy.

(b) A higher age threshold (over 21 years) for diagnosing personality disorders is advised.

(c) The categories of schizoid, dependent and anxious/avoidant personality disorders are not recommended.

(d) The system emphasises that the diagnosis of personality disorders in severe or profound learning disabilities is unlikely.

(e) The problem that these diagnostic criteria have not been primarily designed for use with adults with learning disabilities who offend is noted. (f) Initial diagnosis using the criteria for Personality Disorder - Unspecified is suggested. If these are met, further sub-classification should be considered.

There are no published studies using the DC-LD criteria for personality disorders.

\section{Studies with data on personality disorders in learning disability}

Many of these studies were designed to look not only at personality disorders but also at any form of psychiatric morbidity in learning disability. They vary widely in their methods and findings. The key studies are summarised in Table 1.

\section{DISCUSSION}

Most of the earlier studies included patients drawn from the whole range of learning disability and did not distinguish between personality and behavioural disorders. Some suggested that the diagnosis of personality disorders was unrelated to the level of intellectual disability (Corbett, 1979; Eaton \& Menolascino, 1982). Others did report a relationship - antisocial personality disorders in those with mild learning disability and explosive personality disorders in those with severe learning disability (Day, 1985).

The introduction of the Standardized Assessment of Personality (SAP; Mann et al, 1981) was a crucial development in research in this area. Although initial studies using this instrument were limited to people with mild and moderate learning disabilities (Reid \& Ballinger, 1987; Deb $\&$ Hunter, 1991), it has subsequently been used across the whole range of intellectual ability (Goldberg et al, 1995; Khan et al, 1997). Some of these studies revealed exceptionally high prevalence rates of up to $90 \%$ for different types of personality disorders in learning disability (Goldberg et al, 1995).

The ultimate validity of any diagnosis is in its clinical usefulness. Not surprisingly, therefore, unusually high prevalence rates would raise questions regarding the usefulness of such a diagnosis, particularly in those with severe or profound learning disabilities. Indeed, if diagnostic criteria are applied in such a way that an overwhelming majority of those with learning disability satisfy the criteria for personality disorders, it is not of much clinical use, either for the management of the individual patient or the planning of services.

Two recent studies have examined this issue further. In the first (Naik et al, 2002), those with a clinical diagnosis of personality disorder were identified and ICD-10 (World Health Organization, 1992) criteria applied thereafter. The prevalence rate of $7 \%$ in this study may well be an underestimate of the true prevalence, but nevertheless succeeds in identifying a group of patients with specific care needs and resource implications. The second study (Flynn et al, 2002), apart from estimating the prevalence rate, examined the diagnostic validity in terms of an association with abusive experiences in early life. The authors also introduce the concept of 'severe' personality disorders and suggest criteria for making this diagnosis. This is a novel approach in this field and carries particular significance for the practising clinician.

The diagnosis of personality disorders across the whole spectrum of learning disability is complex and difficult, particularly in those with severe disability. In this context, the need for a personality typology based on the developmental perspective has been highlighted (Gostasson, 1987). Developing consensus diagnostic criteria for each personality disorder, specific for various developmental levels and including objective proxy measures such as behavioural observations and informant accounts is one way forward.

\section{REFERENCES}

Alexander, R.T., Piachaud, J., Odebeyi, L., et al (2002) Referrals to a forensic service in the psychiatry of learning disability. British Journal of Forensic Practice, 4 , 29-33.

American Psychiatric Association (1994) Diagnostic and Statistical Manual of Mental Disorders, (4th edn) (DSM-IV). Washington, DC: APA.

Ballinger, B. R. \& Reid, A. H. (1987) A standardised assessment of personality disorder in mental handicap. British Journal of Psychiatry, 150, 108-109.

_ \& _ (1988) A standardised assessment of personality disorder in mental handicap. British Journal of Psychiatry, 152, 577a.

Bear, D. M. \& Fedio, P. (1977) Quantitative analysis of interictal behaviour in temporal lobe epilepsy. Archives of Neurology, 34, 454-467.

Bouras, N. \& Drummond, C. (1992) Behaviour and psychiatric disorders of people with mental handicaps living in the community. Journal of Intellectual Disability Research, 36, 349-357.

Corbett, J. A. (1979) Psychiatric morbidity and mental retardation. In Psychiatric Illness and Mental Handicap (eds F. E. James \& P. Snaith), pp. II-25. London: Gaskell. 
Craft, M. (1959) Mental disorder in the defective. American Journal of Mental Deficiency, 63, 829-834.

Day, K. (1985) Psychiatric disorder in the middle-aged and elderly mentally handicapped. British Journal of Psychiatry, 147, 660-667.

Deb, S. \& Hunter, D. (1991) Psychopathology of people with mental handicap and epilepsy. III: Personality disorder. British Journal of Psychiatry, I59, 830-834.

Eaton, L. F. \& Menolascino, F. J. (1982) Psychiatric diagnosis in the mentally retarded: types, problems and challenges. American Journal of Psychiatry, 139, 1297-1303.

Flynn, A., Matthews, H. \& Hollins, S. (2002) Validity of the diagnosis of personality disorder in adults with learning disability and severe behavioural problems: Preliminary study. British Journal of Psychiatry, 180, 543-546.

Goldberg, B., Gitta, M. Z. \& Puddephatt, A. (1995)

Personality and trait disturbances in an adult mental retardation population: significance for psychiatric management. Journal of Intellectual Disability Research 39, 284-294.

Gostasson, R. (1987) Psychiatric illness among the mildly mentally retarded. Upsala Journal of Medical Science, 44 (suppl.), II5-124.

Hurley, D. A. \& Sovner, R. (1995) Six cases of patients with mental retardation who have anti-social personality disorder. Psychiatric Services, 46, 828-83.

Jacobson, J.W. (1990) Do some mental disorders occur less frequently among persons with mental retardation? American Journal of Mental Retardation, 94, 596-602.

Khan, A., Cowan, C. \& Roy, A. (1997) Personality disorders in people with learning disabilities, a community survey. Journal of Intellectual Disability Research, 4I, 324-330.

Matson, J. L. (1988) Psychopathology Inventory for Mentally Retarded Adults. Orland Park, IL: International Diagnostic Systems.

Mann, A. H., Jenkins, R., Cutting, J. C., et al (198I) The development and use of a standardized assessment of abnormal personality. Psychological Medicine, II 839-847.

Mavromatis, M. (2000) The diagnosis and treatment of borderline personality disorder in persons with developmental disability -3 case reports. Mental Health Aspects of Developmental Disabilities, 3, 89-97.

Naik, B. I., Gangadharan, S. K. \& Alexander, R.T. (2002) Personality disorders in learning disability - the clinical experience. British Journal of Developmental Disabilities, 48, 95-100.

\section{CLINICAL IMPLICATIONS}

Diagnosing personality disorders in those with learning disability is clinically significant, but there are problems with diagnostic clarity.

- There is a need for consensus diagnostic criteria which use objective proxy measures and are specific for different developmental levels.

- No accurate prevalence figures for personality disorder in learning disability are available.

\section{LIMITATIONS}

Because of a paucity of robust evidence-based studies within the field there may be errors in interpretation of data.

- There have been differing views on what constitutes personality disorder in learning disability over the past 20 years and this may have accounted for some of the variation found.

- The diagnosis of personality disorder in severe learning difficulty is extremely difficult to distinguish from the effects of the disability alone.

REGI ALEXANDER, MRCPsych, Leicester Frith Hospital, Leicester LE3 9QF, UK; SHERVA COORAY, FRCPsych, Parkside NHS Trust, Kingsbury, UK

Correspondence: Dr Regi Alexander, Leicester Frith Hospital, Mansion House, Groby Road, Leicester LE3 9QF, UK

Reid, A. H. \& Ballinger, B. R. (1987) Personality disorder in mental handicap. Psychological Medicine, I7, 983-987.

Reiss, S. (1988) Reiss Screen Test Manual. Orland Park, IL: International Diagnostic Systems.

- (1990) Prevalence of dual diagnosis in community based day programmes in the Chicago metropolitan area. American Journal of Mental Retardation, 94, 578-585.

Royal College of Psychiatrists (200I) Diagnostic Criteria in Learning Disability (DC-LD). London: Gaskell.
Tyrer, P., Casey, P. \& Ferguson, B. (1993) Personality disorder in perspective. In Personality Disorder Reviewed pp. I-16. London: Gaskell.

Wilson, S. R. (200I) A four stage model for management of borderline personality disorder in people with mental retardation. Mental Health Aspects of Developmental Disabilities, 4, 68-76.

World Health Organization (1992) Tenth Revision of the International Classification of Diseases and Related Health Problems (ICD-10). Geneva: WHO. 